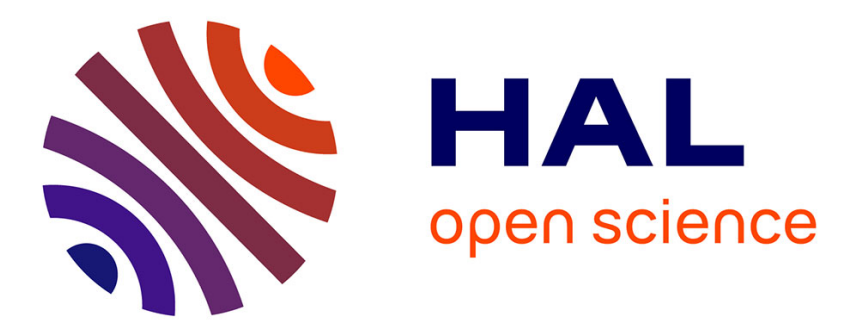

\title{
Use of a redox probe for an electrochemical RNA-ligand binding assay in microliter droplets
}

\author{
Hélène Guyon, François Mavre, Marjorie Catala, Serge Turcaud, Franck \\ Brachet, Benoit Limoges, Carine Tisné, Laurent Micouin
}

\section{To cite this version:}

Hélène Guyon, François Mavre, Marjorie Catala, Serge Turcaud, Franck Brachet, et al.. Use of a redox probe for an electrochemical RNA-ligand binding assay in microliter droplets. Chemical Communications, 2017, 53 (6), pp.1140-1143. 10.1039/c6cc07785d . hal-02185366

\section{HAL Id: hal-02185366 \\ https://hal.science/hal-02185366}

Submitted on 17 Jul 2019

HAL is a multi-disciplinary open access archive for the deposit and dissemination of scientific research documents, whether they are published or not. The documents may come from teaching and research institutions in France or abroad, or from public or private research centers.
L'archive ouverte pluridisciplinaire HAL, est destinée au dépôt et à la diffusion de documents scientifiques de niveau recherche, publiés ou non, émanant des établissements d'enseignement et de recherche français ou étrangers, des laboratoires publics ou privés. 


\section{Journal Name}

\section{COMMUNICATION}

\section{Use of Redox Probe for Electrochemical RNA-ligand Binding Assay in Microliter Droplets}

Received 00th January 20xx, Accepted 00th January 20xx

DOI: $10.1039 / \times 0 \times x 00000 x$

\author{
H. Guyon, ${ }_{\text {Micouin }^{a^{*}}}^{a, b}$ F. Mavré, ${ }^{b}$ M. Catala, ${ }^{c}$ S. Turcaud, ${ }^{a}$ F. Brachet, ${ }^{c}$ B. Limoges, ${ }^{b^{*}}$ C. Tisné, ${ }^{c^{*}}$ and L.
}

www.rsc.org/

In this work, we report an affordable, sensitive, fast and userfriendly electroanalytical method for monitoring the binding between unlabeled RNA and small compounds in microliter-size droplets using a redox-probe and disposable miniaturized screenprinted electrochemical cells

Increasing evidences have shown that non-coding RNAs play a key role in many biological functions and are involved not only in infectious but also in many other human diseases. ${ }^{1}$ Despite an exploding number of biological studies suggesting RNAregulated pathways as potential drug targets, the design of small, drug-like compounds able to selectively bind and modulate RNA functions is still difficult. ${ }^{2}$ This is quite surprising if one considers that interaction with ribosomal RNA is one of the major modes of action of antibiotics ${ }^{3}$ and that small metabolites are known to regulate basic functions of prokaryotes by interacting with riboswitches. ${ }^{4}$

Despite recent important promising developments in computer-aided approaches for the rational design of RNA binders such as Inforna platform, ${ }^{5}$ the most popular methods for the identification and optimization of RNA ligands generally rely on binding assays performed either on drug-like compounds or fragments. ${ }^{6}$ However, many assays used for the design of protein ligands are not fully adapted to the highthroughput screening and quantification of RNA-ligand interactions. As the RNA structure is known to be highly sensitive to chemical modification, especially in the case of conformationally flexible RNAs, any RNA labeling step necessary for the binding visualization can induce experimental bias leading to the selection of compounds that

Laboratoire de Chimie et Biochimie pharmacologiques et toxicologiques, UMR 8601 CNRS, Université Paris Descartes, Sorbonne Paris Cité, UFR Biomédicale, 45 rue des Saints Pères, 75006 Paris, France.

b. Laboratoire d'Electrochimie Moléculaire, UMR 7591 CNRS, Université Paris Diderot, Sorbonne Paris Cité, 15 rue Jean-Antoine de Baïf, 75205 Paris, France.

Laboratoire de Cristallographie et RMN biologiques, UMR 8015, CNRS, Université Paris Descartes, Sorbonne Paris Cité, Faculté de Pharmacie, 4 av. de

l'Observatoire, 75006 Paris, France.

Electronic Supplementary Information (ESI) available: [details of any supplementary information available should be included here]. See DOI: $10.1039 / x 0 x x 00000 x$ do not interact with the natural conformation of the native biomolecule. Furthermore, the selective chemical modification of a complex RNA might be problematic for large RNAs or RNAs with modified nucleotides. Among the currently available high-throughput screening techniques, those based on heterogeneous binding assays (e.g., RNA microarray technologies, SPR imaging) are unfortunately not always representative of the interactions that could occur in homogeneous solution and in particular under cellular conditions. ${ }^{7}$ Hydration shell is indeed known to strongly influence the dynamic structure of RNA, ${ }^{8}$ and solvation is a key parameter to consider when investigating the binding of polar, cationic ligands such as aminoglycosides in aqueous medium. ${ }^{9}$ Another popular screening method is the one based on displacement assay in the presence of a fluorescent reporter. Though this method enables to sensitively monitor homogenous RNA-ligand binding interaction, it can be biased by the general propensity of fluorescent groups to stack on nucleotide bases. In seminal studies on the development of high-throughput fluorescence screens, Rando and Hamasaki have indeed reported that fluorophore-containing analogues of paromomycin exhibit a ten-fold improved affinity to $16 \mathrm{~S}$ RNA constructs compared to paromomycin itself. ${ }^{10}$ This result suggests that the fluorophore is not a neutral tag and can significantly contribute to the binding energy of the probe, leading to the selection of tag-like (dyes-like) competitors. ${ }^{2 b}$ By virtue of their simplicity, short detection time, high sensitivity in low volume samples, low-cost instrumentation, compatibility with direct analysis in coloured or nontransparent biological samples, and high-throughput capability using disposable electrochemical microplates, ${ }^{11}$ electroanalytical methods appear as good candidates for implementing simple and fast high-throughput RNA-ligand binding assays. So far electrochemical monitoring of oligonucleotide/small molecule interactions have been mainly developed in the context of analytical applications in combination with structure-switching aptamers immobilized on an electrode surface for rapid and sensitive quantification of target analytes. ${ }^{12}$ It is only recently that two studies have 
reported electrochemical detection strategies for monitoring the homogeneous binding recognition between an aptamer and a protein ${ }^{13}$ or a small molecule, ${ }^{14}$ allowing thus to get rid of drawbacks encountered with heterogeneous binding assays. These two approaches are based on the electrochemical measurement of diffusion rate difference between a small redox-active compound free-to-diffuse in solution and the same compound bound to its DNA aptamer. ${ }^{15}$

Taking advantage of a related simple and flexible electrochemical detection strategy, we report here that homogenous electrochemical binding assay is not restricted to the interaction study of a small molecule with an aptamer specifically designed to recognise it, but can be extended to the more general case of a relevant druggable RNA target and non-redox active ligands.

The general principle of the competitive homogeneous electrochemical binding assay we have developed for characterizing the binding reaction between an RNA receptor and a targeted small ligand is depicted in Fig. 1 (top).

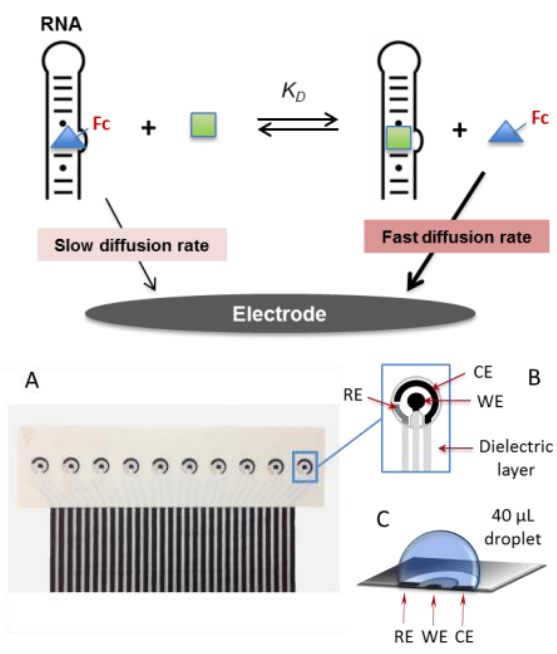
Fig 1. Top: General principle of the homogeneous competitive electrochemica $\mathrm{Fc}$ on the scheme) that competes with the unlabeled targeted ligand (gree square) for binding to RNA diffuses faster towards the electrode surface and therefore, is more easily detected as compared to the bound form in a same homogeneous solution. Bottom: A) Array of ten miniaturized screen-printe electrochemical cells. B) The inset is a zoom on an individual electrochemical cell showing the three screen-printed electrodes and the surrounding dielectric laye delimiting a circular well. Ref: Ag/AgCl reference electrode, WE: workin
electrode, CE: counter-electrode. C) Droplet on the electrochemical cell.

It relies on the monitoring by cyclic voltammetry (CV) of the faradaic current response of a free-to-diffuse redox-labeled ligand in solution in the presence of fixed RNA receptor concentration and an increasing concentration of a nonlabeled targeted ligand, taking thus advantage of the differential diffusion rates that exists between the redoxlabeled ligand under free and RNA-bound forms. The unbound redox-labeled ligand, because of its smaller size, diffuses faster towards the electrode surface and therefore, is more easily detected as compared to the RNA-bound form in a same homogeneous solution. The key advantages of this technique are that it does not require any chemical modification of RNA nor its immobilization on a solid support. Moreover, according to the relative insensitivity of electrochemical methods to downscaling (in contrast to optical ones which sensitivity depends on the Beer-Lambert law), the approach enables to operate in very small volume samples, which is particularly attractive for assays involving low-abundance or expensive biological reagents. With the aim to achieve a large number of experiments in parallel using small volume samples, and also to demonstrate the high-throughput capability offers by this novel approach, single-use arrays of 10 independently addressable screen-printed electrochemical cells, well adapted for performing the binding experiments in small droplets of 30 to $50 \mu \mathrm{L}$, were used (Fig. 1, bottom).

Aminoglycosides are natural product classes that target ribosomal RNA and that were extensively used as a general scaffold to devise RNA binders. ${ }^{16}$ For this proof of concept, we first investigated the binding of several aminoglycosides such as neomycin 1, paromomycin $\mathbf{2}$ and neamine $\mathbf{3}$ to 16S23 RNA, a 23-nucleotide hairpin mimicking the decoding A-site of bacterial $16 \mathrm{~S}$ ribosomal RNA. We first designed the redox probe 4 (FcPRM) from paromomycin 2 substituted with a ferrocenyl group in a position presumably not detrimental for a binding to its natural target, the bacterial ribosomal 16S RNA (Scheme 1). ${ }^{17}$

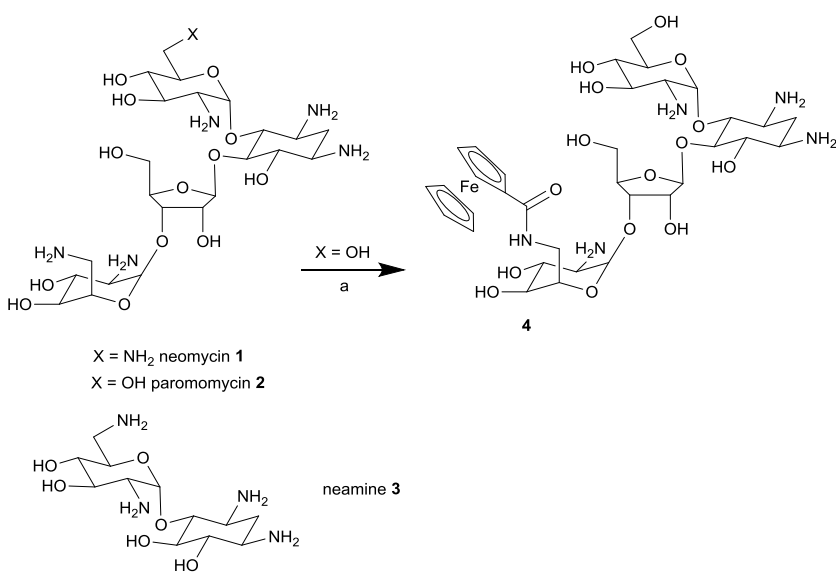
Scheme 1. Aminoglycosides investigated in this study and synthesis of redox DMSO, $12 \mathrm{~h}$, r.t. $32 \%$. See ESI for details.

Electrochemical experiments were then achieved by $\mathrm{CV}$ to characterize the new redox probe. The characteristic reversible wave for the one-electron oxidation of the ferrocenyl group was observed at a formal potential $E^{0}=+0.38 \mathrm{~V}(\mathrm{vs}$. $\mathrm{Ag} / \mathrm{AgCl})$ in a $10 \mathrm{mM}$ MES buffer at $\mathrm{pH} 5.5$ supplemented with $150 \mathrm{mM}$ $\mathrm{NaCl}$ and $0.1 \mathrm{mM}$ EDTA. Throughout the entire CV measurements, we were able to witness the stability of this water-soluble ferrocenoyl derivative which comforted us in the use of this molecule as a redox-active probe.

The binding of the FcPRM probe to 16S23 RNA was first characterized by NMR spectroscopy. 1D and TOCSY experiments confirmed that $\mathbf{4}$ and paromomycin share the same binding site on 16S23 RNA (Fig. S4, ESI) despite the presence of the ferrocenyl moiety. We next investigated the $\mathrm{CV}$ peak current intensity change upon addition of increasing quantity of RNA (Fig. 2). 

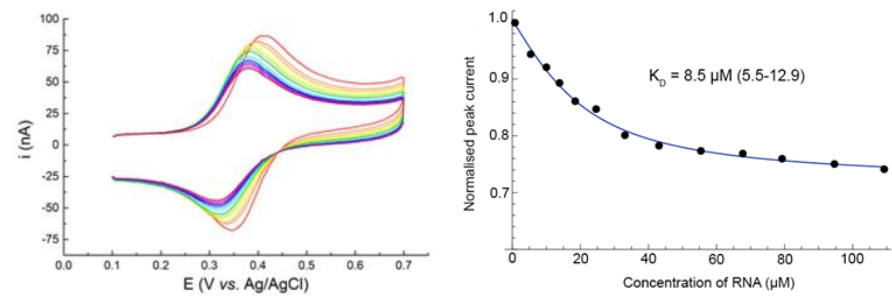

Fig 2. Measurement of $K_{\mathrm{D}}$ between compound $4(15 \mu \mathrm{M})$ and $16 \mathrm{~S} 23$ RNA by CV in $10 \mathrm{mM}$ MES buffer ( $\mathrm{pH} 5.5$ ) supplemented with $150 \mathrm{mM} \mathrm{NaCl}$ and $0.1 \mathrm{mM}$ EDTA. Left: CVs (scan rate $v=0.1$ V.s $)$ of compound $4(15 \mu \mathrm{M})$ upon addition of increasing amount of $16 \mathrm{~S} 23$ RNA. Right: Normalized anodic peak curren response as a function of $16 S 23$ RNA concentration. $K_{D}$ is indicated with a $95 \%$ confidence interval in bracket. See ESI for details.

As expected, the $16 \mathrm{~S} 23$ RNA/FcPRM complex diffuses at a slower rate to the electrode surface than the free form of the probe, and the addition of RNA hence gradually led to a decrease of the anodic and cathodic peak currents (Fig. 2, left). The dissociation constant value $\left(K_{\mathrm{D}}\right)$ of the probe was recovered from the non-linear least-square hyperbolic regression fitting of the titration curve (conducted in triplicates) obtained by plotting the variations of the anodic peak current $\left(\mathrm{Fc}^{+}\right)$as a function of RNA concentration (Fig. 2 right and Fig. S2, ESI). A one binding site model was used assuming a dynamic equilibrium between the free and bound reduced and oxidized forms of FCPRM on the time scale of the $\mathrm{CV}$ experiments (i.e. binding reactions were considered as fast and always at equilibrium in comparison to the electron transfer kinetics). ${ }^{18}$ An average $K_{\mathrm{D}}$ of $7.8 \mu \mathrm{M}$ could be extracted from the three independent CV titrations. To assess the reliability of the method, the dissociation constant of $16 \mathrm{~S} 23$ RNA/FcPRM complex was independently determined by Isothermal Titration Calorymetry (ITC) ${ }^{19}$ (Fig. S3, ESI). A $K_{\mathrm{D}}$ value of $9.3 \mu \mathrm{M}$ was obtained which is close to that determined electrochemically, clearly demonstrating the good reliability of the electrochemical binding assay. Therefore, the proper binding of compound 4 to the 16S23 RNA hairpin and the demonstration that we can efficiently determine the $K_{\mathrm{D}}$ value of the $16 \mathrm{~S} 23$ RNA/FcPRM complex by CV supported the use of FcPRM 4 as a displaceable redox spy probe to monitor aminoglycoside/RNA interactions electrochemically. It is worth to note that, concomitantly to the peak currents decrease, a progressive negative shift of the formal potential of the reversible wave was observed with the increasing amount of RNA. On the basis of this negative shift of the formal potential at the end of the titration (i.e., $\Delta E \sim-30 \mathrm{mV}$ ), the relative affinity binding between the oxidized and reduced form of the redox probe (i.e., $\left.\Delta E=-R T / F \operatorname{Ln}\left(K_{\mathrm{D}, \mathrm{ox}} / K_{\mathrm{D}, \text { red }}\right)\right)$ can be estimated. This leads to a 2.6 -fold increase in the affinity binding of the oxidized form (i.e., ferrocenium) of the ferrocene-labeled paromomycin (i.e. $K_{\mathrm{D}, \mathrm{ox}}=3.0 \mu \mathrm{M}$ ) compared to its neutral reduced form, an effect that might be attributed to the positive charge generated on the ferrocenyl moiety that may help to further stabilize the binding to RNA.

We then investigated the binding of several aminoglycosides such as neomycin 1, paromomycin 2 and neamine $\mathbf{3}$ to $16 \mathrm{~S} 23$ RNA by competition experiments. Experiments were first conducted using paromomycin 2. A progressive displacement of the redox probe 4 could be monitored through the increase of both oxidation and reduction current intensities upon addition of an increasing amount of paromomycin $\mathbf{2}$ to the preequilibrated probe 4/16S23 RNA complex. A $K_{\mathrm{D}}$ value of $1.5 \mu \mathrm{M}$ was estimated based on the anodic current variation as a function of paromomycin concentration and the previously determined $K_{\mathrm{D}}$ of FcPRM (Fig. 3A). Interestingly, this competition experiment showed that paromomycin 2 and paromomycin-derived probe 4 bind to 16S23 RNA with very close dissociation constants, 4 being only slightly less affine. This lower affinity might be explained by lower electrostatic interactions with compound $\mathbf{4}$ due to the presence of the neutral ferrocenyl group in place of the positively charged amino group in 2. Overall, this result confirms that the ferrocenyl moiety, as opposed to fluorophores, does not significantly alter the interaction of conjugated aminoglycosides with RNA.
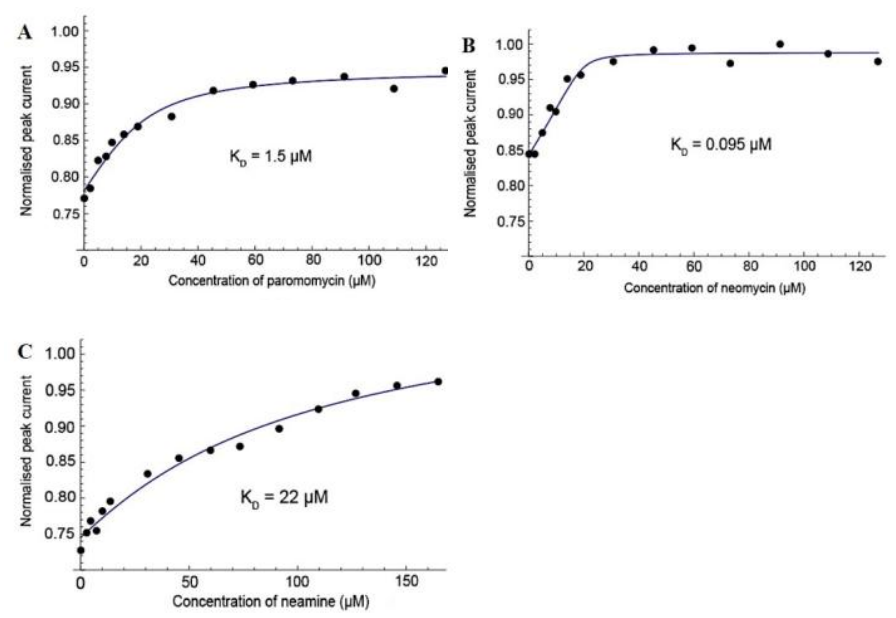

Fig 3. Electrochemical competitive binding curves obtained in the presence of FCPRM $4(29 \mu \mathrm{M}$ for A and B, and $27 \mu \mathrm{M}$ for C), 16S23 RNA (0.7 or $1.3 \mathrm{eq}$ ) and increasing amount of the competing aminoglycoside. Normalized anodic peak (B) neomycin, and (C) neamine. See ESI for details.

The dissociation constants of two other aminoglycosides, i.e. neomycin (Fig. 3B) and neamine (Fig. 3C), to $16 \mathrm{~S} 23$ RNA were also determined by competitive electrochemical binding experiments. Interestingly, $K_{\mathrm{D}}$ values of $0.09 \mu \mathrm{M}$ and $22 \mu \mathrm{M}$ were obtained for neomycin 1 and neamine 3, respectively. The $K_{\mathrm{D}}$ values of these three aminoglycosides for $16 \mathrm{~S} 23$ RNA are in agreement with ranking previously obtained using other techniques such as $1 \mathrm{TC},{ }^{20} \mathrm{SPR}^{21}$ or ${ }^{19} \mathrm{~F}$ NMR spectroscopy. ${ }^{22}$ These results definitely validate the use of the present electrochemical detection strategy for screening and ranking 16S RNA binders with affinities ranging from 0.1 to $20 \mu \mathrm{M}$ with a single redox probe.

We then investigated whether redox probe 4 , designed to quantify the interaction with 16S23 RNA, could be used with other RNA-small molecule pairs. For this purpose, we investigated if FCPRM 4 could be a ligand for a known neomycin riboswitch (Neo-switch) ${ }^{23}$ and if we could quantify the interaction of neomycin with its riboswitch by our method. 
First, we checked by NMR spectroscopy that FcPRM 4 binds to the neomycin riboswitch and does not prevent its folding (Fig. S8, ESI). Then, a $K_{\mathrm{D}}$ value of $480 \mathrm{nM}$ between the redox 4 and Neo-switch could be determined using CV (Fig. 4A and Fig. S9, ESI). Finally, a competition titration with neomycin $\mathbf{3}$ and the Neo-switch bound to FCPRM 4 could be monitored by CV (Fig. $4 \mathrm{~B}$ and Fig. S10, ESI), leading to the determination of a $K_{\mathrm{D}}$ value close to $10 \mathrm{nM}$.
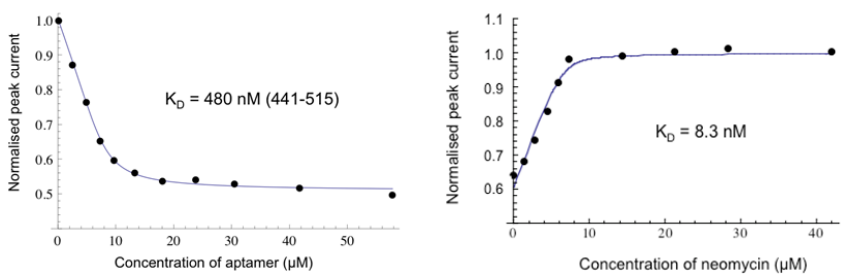

Fig 4. (A) Measurement of KD between compound $\mathbf{4}$ and Neo-switch by CV in 10 Competition experiment monitored by CV with neomycin 3. See ESI for details.

In conclusion, we have demonstrated that ferrocene-labeled paromomycin can be used as an efficient redox spy probe to evaluate the binding of several aminoglycosides to 16S RNA or to an RNA riboswitch, taking advantage of an electrochemical homogeneous competitive binding assay in a few microliter sample volumes. This work is the first demonstration of the use of CV to detect and quantify the interaction between small molecules and a biological target RNA in an homogeneous screening assay. This proof of concept highlights the simplicity, rapidity and low cost of this method, which does not require any functionalization of neither the target RNA nor the ligand or the electrodes. The generality of this method is illustrated by the fact that the same probe can be used for the evaluation of binding affinities of several small molecules for different RNA targets. As aminoglycosides are general RNA-friendly ligands, we can assume that redox probe 4 could be used for the investigation of RNA-ligand interaction with many other RNA targets. ${ }^{16}$ Finally, this technique, able to quantify from micromolar to nanomolar interactions, could potentially be developed for high-throughput binding assays, wherein the binding of several organic molecules to RNA would be tested in parallel using disposable screen-printed 96-well electrochemical microtiter plates. ${ }^{11}$ This work is currently under investigation in our laboratories.

Financial support from USPC (IDEX project CEREAL) and CNRS is acknowledged.

\section{Notes and references}

1 (a) T. A. Cooper, L. Wan and G. Dreyfuss, Cell, 2009, 136 777; (b) M. Esteller, Nat. Rev. Genet., 2011, 12, 861; (c) P. A Sharp, Cell, 2009, 136, 577.

2 (a) L. Guan and M. D. Disney, ACS Chem. Biol., 2012, 7, 73. (b) M. D. Shortridge and G. Varani, Curr. Opin. Struct. Biol., 2015, 30, 79 .
3 (a) J. Poehlsgaard and S. Douthwaite, Nat. Rev. Microbiol., 2005, 3, 870; (b) D. N. Wilson, Nat. Rev. Microbiol., 2014, 12, 35.

4 (a) A. Serganov and E. Nudler, Cell, 2013, 152, 17. (b) J. K. Soukup and G. A. Soukup, Curr. Opin. Struct. Biol., 2004, 14, 344.

5 (a) M. D. Disney, A. M. Winkelsas, S. P. Velagapudi, M. Southern, M. Fallahi and J. L. Childs-Disney, ACS Chem. Biol., 2016, 11, 1720; (b) S. P. Velagapudi, S. J. Seedhouse and M. D. Disney, Angew. Chem., Int. Ed., 2010, 49, 3816.

6 (a) M. D. Disney, I. Yildirim and J. L. Childs-Disney, Org. Biomol. Chem., 2014, 12, 1029; (b) J. Pai, S. Hyun, J. Y. Hyun, S. H. Park, W. J. Kim, S. H. Bae, N. K. Kim, J. Yu and I. Shin, J. Am. Chem. Soc., 2016, 138, 857; (c) S. G. Rzuczek, M. R. Southern and M. D. Disney, ACS Chem. Biol., 2015, 10, 2706; (d) T. Tran and M. D. Disney, Nat. Commun., 2012, 3, 1125; (e) S. P. Velagapudi and M. D. Disney, Chem. Commun., 2014, 50, 3027; (f) S. P. Velagapudi, S. M. Gallo and M. D. Disney, Nat. Chem. Biol., 2014, 10, 291.

7 A. N. Rao and D. W. Grainger, Biomater. Sci., 2014, 2, 436.

8 19. M. T. Sykes and M. Levitt, Proc. Natl. Acad. Sci. U S A, 2007, 104, 12336.

9 A. C. Vaiana, E. Westhof and P. Auffinger, Biochimie, 2006, 88, 1061.

10 K. Hamasaki and R. R. Rando, Anal. Biochem., 1998, 261, 183

11 (a) F. Kivlehan, F. Mavre, L. Talini, B. Limoges and D. Marchal, Analyst, 2011, 136, 3635. (b) S. Piermarini, L. Micheli, N. H. Ammida, G. Palleschi and D. Moscone, Biosens. Bioelectron. 2007, 22, 1434.

12 (a) E. E. Ferapontova, E. M. Olsen and K. V. Gothelf, J. Am. Chem. Soc., 2008, 130, 4256; (b) M. Jarczewska, Ł. Górski and E. Malinowska, Anal. Methods 2016, 8, 3861. (c) A. A. Lubin and K. W. Plaxco, Acc. Chem. Res., 2010, 43, 496.

13 Y. Cao, D. Chen, W. Chen, J. Yu, Z. Chen and G. Li, Anal. Chim. Acta, 2014, 812, 45.

14 L. Challier, F. Mavre, J. Moreau, C. Fave, B. Schollhorn, D. Marchal, E. Peyrin, V. Noel and B. Limoges, Anal. Chem., 2012, 84, 5415

15 J. Moreau, L. Challier, N. Lalaoui, F. Mavre, V. Noel, B. Limoges, B. Schollhorn and C. Fave, Chem. Eur. J., 2014, 20, 2953.

16 J. L. Houghton, K. D. Green, W. Chen and S. GarneauTsodikova, Chembiochem, 2010, 11, 880.

17 D. Fourmy, M. I. Recht, S. C. Blanchard and J. D. Puglisi, Science, 1996, 274, 1367.

18 A. De Rache, C. Buess-Herman and T. Doneux, Electroanal. Chem., 2015, 745, 44

19 M. Kaul and D. S. Pilch, Biochemistry, 2002, 41, 7695

20 (a) M. Kaul and D. S. Pilch, Biochemistry, 2002, 41, 7695

21 (a) C. H. Wong, M. Hendrix, E. S. Priestley and W. A. Greenberg, Chem. Biol., 1998, 5, 397. (b) T. Tran and M. D. Disney, Biochemistry, 2010, 49, 1833.

22 T. Lombes, R. Moumne, V. Larue, E. Prost, M. Catala, T. Lecourt, F. Dardel, L. Micouin and C. Tisne, Angew. Chem., Int. Ed., 2012, 51, 9530.

23 (a) J. E. Waigand, M. Sanchez, E. B. Gunnesch, S. Zeiher, R. Schroeder, B. Suess, RNA, 2008, 14, 89. (b) E. DuchardtFerner, J. E. Weigand, O. Ohlenschläger, S. R. Schmidtke, B. Suess, J. Wöhnert, Angew. Chem. Int. Ed., 2010, 49, 6216. 